\title{
Management of Reputational Risk for Benan Island Marine Tourism, Lingga, Indonesia
}

\author{
Jack Febriand Adel ${ }^{1}$, Asmaul Husna ${ }^{2}$, Sri Ruwanti ${ }^{3}$, Ardiansyah $^{4}$ \\ \{jackfebriandadel@umrah.ac.id ${ }^{1}$ \}

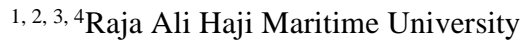

\begin{abstract}
This study aims to improve the effectiveness in the management of reputational risk of Benan Island Marine Tourism. This study uses a qualitative research approach. Data collection techniques include observation sheets assisted by a video recorder, and interview sheets used for direct a indirect interviews with the aid of a video recorder. The results of the study are in the form of determining the purpose and objectives of Benan Island Marine Tourism reputational risk management, followed by the organization of Benan Island Marine Tourism reputational risk management organization, and identification, measurement and monitoring of Benan Island Marine Tourism reputation risk. The final discussion covers the reputational risk control mechanism for benan island marine tourism.
\end{abstract}

Keywords: Reputational Risk, Risk management, Risk Management, Risk Control.

\section{Introduction}

Tourism is a multi-sectoral industry with a very high level of competition, especially during the COVID-19 pandemic. One of the tourist destinations that is being developed in the Riau Islands Province is Benan Island, which is located in Lingga Regenc. The potential of the Benan Island tourism industry is the beauty of the beach, clear water, small islands, and a stretch of sandy beach. Benan Island is shaped like a small bow that shoots towards the South China Sea and is adjacent to Katang Island, Nopong Island and Merodong Island.

The management of reputational risk of tourist destinations is very important. A location becomes a tourist destination only through the act of marketing, through the narratives and images that are communicated. Reputational risk is inherent in every activity carried out. Managing risk effectively is one of the keys to the survival and success of the tourism industry. The Benan Island Marine Tourism destination already has a Tourism Awareness Group (POKDARWIS) which was formed through Village Head Decree Number 100/KPTS/140/2019. This POKDARWIS is tasked with assisting the Village Government to develop local tourism potential, promote local cultural values, create new jobs, develop creative industries and reduce unemployment.

\section{Theoretical Framework}


Reputational risk is the risk of a decrease in the level of tourists' trust that comes from negative perceptions of a tourist destination. The reputational risk can arise, among others, due to tourist complaints, negative media reports and/or rumors, and an ineffective tourism marketing strategy. Reputational risk management is a set of methodologies and procedures used to identify, measure, monitor, and control reputational risk arising from all marine tourism activities, including efforts to mitigate and/or minimize financial and non-financial losses that may arise from tourism activities, includes the relationship between the people with tourists and other stakeholders. The main objective of reputational risk management is to anticipate and minimize the impact of losses from the reputational risk.the recording and administration of the data is compiled as statistical data that can be used to project potential losses over a certain period from the activities.

\section{Research Method}

This study uses a qualitative research approach. Data collection techniques include observation sheets assisted by a video recorder, and interview sheets used for direct a indirect interviews with the aid of a video recorder. Several sources of information to identify and measure the impact of Reputational Risk, including mass media coverage, the Benan Island Marine Tourism website and analysis of social networks and tourist complaints through the tourist satisfaction questionnaire service. In line with the development of tourism that continues to change, it is possible to shift the attention and interest of stakeholders to Benan Island Marine Tourism. For this reason, it is necessary to have an understanding of tourists and their needs through regular tourist mapping.

\section{$4 \quad$ Results}

Based on the data that has been collected, several things related to the implementation of the reputation risk of marine tourism in Benan Island can be explained:

1. Benan Island marine tourism has not implemented reputation risk management.

2. has not been documented related to the risk of the reputation of marine tourism on the island of Benan

3. the absence of an organization that specifically manages the reputation risk of marine tourism on the island of Benan

4. the process of identification, measurement and monitoring of Benan Island Marine Tourism Reputational Risk has not yet been implemented.

5. the process ofBenan Island Marine Tourism Reputation Risk control mechanism has not yet been implemented.

\section{$5 \quad$ Discussions}

\subsection{Development of the Benan Island Marine Tourism reputational risk management}




\section{organization}

Reputational risk management organization, including the implementation of risk management for reputational risk by POKDARWIS, the public and other stakeholders, can be described as follows:

1. Reputational risk management is carried out by POKDARWIS, the community and other stakeholders.

2. All POKDARWIS, community and other stakeholders are part of the reputational risk management implementing structure, considering that all Benan Island Marine

Tourism activities are involved in creating the reputation of the island. reputation is the result of. The role of POKDARWIS is to identify reputational risk that occurs in Benan Island Marine Tourism activities and as a front liner in building and preventing reputational risk.

POKDARWIS carries out the risk management function for reputational risk, and is responsible for:

1. Carrying out public relations functions and following up on negative news or other events that affect the reputation of Benan Island Marine Tourism;

2. Handle and resolve tourist complaints.

3. Communicating information needed by stakeholders, including tourists, the community and other stakeholders.

\subsection{Identification, measurement and monitoring of benan island marine tourism reputational risk}

POKDARWIS must record and administer every incident related to reputational risk including the amount of potential loss caused by the incident in a data administration. The recording and administration of the data is compiled as statistical data that can be used to project potential losses over a certain period from the activities of Benan Island Marine Tourism.

POKDARWIS can use several sources of information to identify and measure the impact of Reputational Risk, including mass media coverage, the Benan Island Marine Tourism website and analysis of social networks and tourist complaints through the tourist satisfaction questionnaire service.

In line with the development of tourism that continues to change, it is possible to shift the attention and interest of stakeholders to Benan Island Marine Tourism. For this reason, it is necessary to have an understanding of tourists and their needs through regular tourist mapping.

\subsection{Benan Island Marine Tourism reputation risk control mechanism}

POKDARWIS uses several sources of information to identify and measure the impact of reputational risk. The indicators that are believed to influence the formation of the reputation of Benan Island Marine Tourism are as follows:

1. Reputation Effect of POKDARWIS and related Tourism Business Owners.

Negative news is one of the factors that can increase the reputational risk of Benan Island Marine Tourism and effect POKDARWIS and related Tourism Business Owners.The measurements and indicators are:

- The credibility of POKDARWIS and related Tourism Business Owners 
- Reputational risk events carried out by POKDARWIS and related Tourism Business Owners

2. Business Ethics Violation

In this case, what needs to be considered is that POKDARWIS and related Tourism Business Owners violated generally accepted business ethics/norms. The measurements and indicators are:

- Transparency of financial information

- Business cooperation with other stakeholders

3. POKDARWIS Business Cooperation and Related Tourism Business Owners

Cooperation with business partners can be exposed to Reputational Risk if there is a misunderstanding in the use of services or negative news among business partners. The measurements and indicators are:

- The amount and materiality of POKDARWIS cooperation and Tourism Business Owners related to business partners

1. Frequency, Materiality and Exposure to Negative Reports of POKDARWIS and related Tourism Business Owners. Frequency, type of media, and materiality of negative news as measured during the assessment period. The measurements and indicators are:

- Frequency and materiality of reporting

- Type of media and scope of coverage

2. Frequency and Materiality of tourist complaints measured during the assessment period. The measurements and indicators are:

- Frequency of tourist complaints

- Materiality of tourist complaints

Reputational risk monitoring is carried out in the form of reports, including:

1. The Risk Profile Report contains a summary and analysis of news from print and online media for each reporting period.

2. The Tourist Complaint Report contains the number of incoming tourist complaints and the percentage of tourist complaints that were resolved.

3. POKDARWIS immediately follows up and resolves tourist complaints that could otherwise increase Reputational Risk exposure.

4. POKDARWIS develops a reliable mechanism in carrying out effective Reputational Risk control measures.

In general, reputational risk control can be carried out in two ways; through prevention of events that cause reputational risk and improving systems to reduce loss caused by reputational risk.

1. The prevention of events that cause Reputational Risk, are generally carried out through a series of activities as follows:

2. A series of activities carried out by POKDARWIS for community empowerment in the form of economic/social activities which are expected to build a positive reputation from tourists towards Benan Island Marine Tourism.

3. Regular communication/socialization with tourists in order to form a positive reputation from tourists

4. Restoration of the reputation of Benan Island Marine Tourism after an incident that 
causes Reputational Risk, namely an immediate response to restore reputation and prevent the deterioration of the reputation of Benan Island Marine Tourism.

5. Mitigation of reputational risk and events that give rise to reputational risk is carried out by considering the materiality of the problem and costs. Nevertheless, the reputation risk may be accepted as long as it is still in accordance with the level of risk to be taken.

In the context of controlling reputational risk, the preventive measures and recovery after an event that threatens the reputation of the destination needs to be followed by improvements to control weaknesses and procedures that trigger reputational risk.

To implement an effective internal control system that can reduce the risk of loss, the following steps must be taken, namely:

- Benchmarking, by surveying the ranking of Benan Island Marine Tourism among other similar tourism destinations.

- Monitoring and evaluating of reputation is based on the need to:

- See if the goal of establishing the high reputation of Benan Island Marine Tourism can be achieved

- Determine the direction and policies as well as the necessary improvements in an effort to establish a good reputation for Benan Island Marine Tourism,

- Reporting is a form of written report of internal and external communication activities on issues, communication programs or certain activities that are considered to have an impact on the reputation of Benan Island Marine Tourism.

The management of Benan Island Marine Tourism reputation risk during the Covid-19 Pandemic was carried out through the establishment of a standard Crisis Contingency Plan, consisting of:

1. Review the problem or chronology

2. Information flow

3. Determination of personal in charge

4. Determination of authority and spokesperson

5. Schedule of crisis management activities

6. Alternative communication strategy

7. Evaluation 


\section{References}

[1] Committee of Sponsoring Organizations of the Treadway Commission (COSO). 2004. Enterprise Risk Management - Integrated Framework. Executive Summary. Copyright (C) 2004 by the Committee of Sponsoring Organizations of the Treadway Commission. All rights reserved.

[2] Deloitte Risk Advisory. 2016. Reputation matters. Developing reputational resilience ahead of your crisis. Copyright @ June 2016 by Deloitte. All rights reserved.

[3] Hoffman, D. 2002. Managing Operational Risk, John Wiley \& Sons, Inc.

[4] Regan, S. 2003. Risk implementation and analysis. AACE International Transaction.

[5] Vaughn, Emmet. 1996. Risk Management, New Jersey: John Wiley \& Sons Inc, Canada. 